\title{
for the Study of Religion
}

Is There Room for Theory in the Study of Religion?

A Question Revisited

Philip L. Tite

What's Old Is New Again, But Still Pretty Old:

Searching for a Post-Theory Turn in Religious Studies Craig R. Prentis

The Museum Caught in a Maelstrom of Narratives:

Exhibiting Islam in Europe

Göran Larsson

On Theology in the Academy

Jason N. Blum

Geographies of Religion as Theological Ontologies:

A Difficult Rapprochement with Religious Studies

Justin K. H. Tse

Quaker Studies in Critical Perspective

Jon R. Kershner

Religion, Theory, Critique, and Epistemological Anarchy: A Review Essay

Tenzan Eaghll 


\section{Bulletin for the Study of Religion}

The Bulletin publishes articles that address religion in general, the history of the field of religious studies, method and theory in the study of religion, and pedagogical practices. Research featured in the Bulletin has covered and will continue to cover diverse religious traditions from any time period (from ancient religions to new religious movements), but articles published in the Bulletin are typically distinguished by their social scientific methods (e.g., historical, sociological, anthropological, cognitive scientific) or critical theory apparatus (i.e., postcolonialist, poststructuralist, neomarxist). The Bulletin is unique in that it offers a forum for various academic voices to debate and reflect on the ever-changing state of the field, and insofar as it encourages scholars continually to engage meta-level questions at the leading edge of inquiry. The Bulletin is presently published in print and online.

The Bulletin is published four times a year in March, June, September, and December by Equinox Publishing Ltd., Office 415, The Workstation, 15 Paternoster Road, Sheffield S1 2BX, United Kingdom,

\section{Editors}

Philip L. Tite (University of Washington)

Robert A. Segal (University of Aberdeen)

\section{Managing Editor}

Arlene Macdonald (University of Texas Medical Branch)

Book Review Editor

Adam Miller (University of Chicago)

\section{Production Editor}

Chas S. Clifton (Colorado State University, Pueblo)

\section{Editorial Board}

Wendy Dossett (University of Chester), David Feltmate (Auburn University), Susan Henking (Shimer College), Michael Jerryson (Youngstown University), Brent Nongbri (Aarhus University), Nathan Rein (Ursinus College) Bryan Rennie (Westminster College), Donovan Schaefer (Trinity College, Oxford), Ann Taves (University of California, Santa Barbara).

All manuscripts should be submitted through our online submission system: http:/ / www.equinoxpub.com/BSOR/ about/submissions. Announcements and inquiries should be sent to the editor, Philip L. Tite (philip.tite@mail.mcgill.ca).

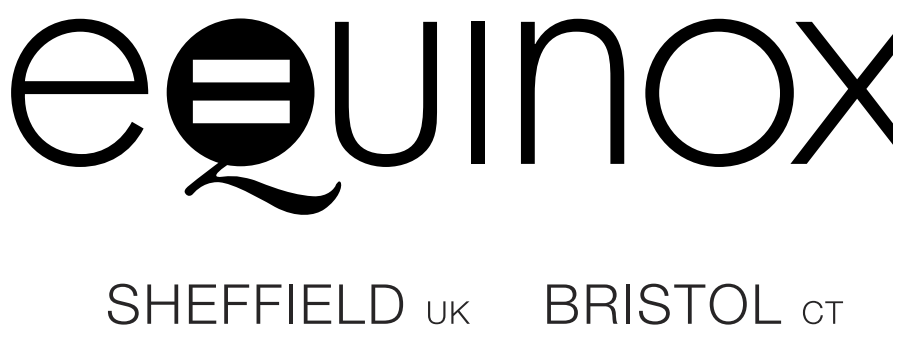

Subscriptions: For subscription prices, notes on ordering, and customer service, see http://www.equinoxjournals.com/ojs/index.php/BSOR/about/subscriptions.

Abstracted/Indexed by ATLA Religion Database ${ }^{\circledR}$ and Religious and Theological Abstracts.

Advertising: For details contact Journals Department, Equinox Publishing Ltd. at the above address or email vhall@equinoxpub.com.

Postmaster: Send address changes to Bulletin for the Study of Religion, ISD, 70 Enterprise Drive, Suite 2, Bristol, CT 06010

(C) Equinox Publishing Ltd. 2019

ISSN 2041-1871 (online); 2041-1873 (print)

Printed in the United States by The Sheridan Press. 


\section{Is There Room for Theory in the Study of Religion? A Question Revisited}

doi 10.1558/bsor.39920

Sixteen years ago, while a doctoral student at McGill University, I wrote my final editorial introduction to a journal I had edited for four years with the question: "Is there room for theory in religious studies?" (Tite 2003). That question had shaped most of my editorship of ARC: The Journal of the Faculty of Religious Studies, McGill University. While a graduate student I had caught the "theory bug" and I used my role as editor to encourage reflections and debates over theory, pedagogy, and the profession. Over the past seven or eight years that I have edited the Bulletin, the same question has driven much of what we have done-be that in the pages of the journal, on the Bulletin's blog or Facebook group, or during professional collaborations such as with SORAAD and NAASR. As I come to the finale of my editorship of the Bulletin, I want to revisit this question, weaving together some of what I wrote years ago with my thoughts today.

The word "theory" comes from the Greek theoria, which simply means "to view" or "to watch," including to "reflect" upon. For many academics, theory tends to be used in very broad applications, denoting interpretative frameworks, cultural or epistemological paradigms, diverse approaches or methods in analyzing data sets, and self-reflexive endeavors that have little to do with data. I've taught multiple courses in theory in the study of religion, at both undergraduate and graduate levels, and have worked theory into every course I teach. Like many others, I list "method and theory" among my teachable topics.

Theory is a hot topic today, and everyone seems to be doing it, though few know anything about it. When theory is seen in such broad terms, the term ceases to serve any functional value. Indeed, all becomes theory and therefore theory becomes all things (for a helpful overview of diverse theories of religion, see Stausberg and Engler 2016). An impasse occurs, and we return to our nauseated attitude ("Can't we forget all this theory crap and get back to studying religion?"), concluding that all talk of theory is simply to babble away in endless circles of meaninglessness and, at the very worst, narcissistic scholarly self-reflexivity coupled with belittling critiques of other academics. If this were all I meant by theory, then I would surely agree; I would unequivocally advocate the "death of theory" and warn my students against the futility, indeed the parasitical danger of theorizing! Thankfully, "theory" need not be meaningless, self-absorbed, or destructive. Rather, theory is the exploration of the epistemological

VOLUME 48 , NOS. 1-2 / MARCH-JUNE 2019 field (the episteme) from which facts, knowledge, and the normative arise (cf. Foucault 1994, xxii). An apt analogy, drawn from Michel Foucault's The Order of Things, is an operating table where everything is laid out, delimited, and organized for cataloguing and critical examination (Foucault 1994, xvii, xix, xxiv).

During my tenure as editor, I have spent a great deal of my time reassessing the place of theory in the study of religion-and the human sciences in general-often by collaborating and occasionally clashing with those who see themselves as theorists in the academic study of religion. I have come to the conclusion that to theorize religion is to explore the processes, histories, and epistemological agendas at play in "the view" that scholars perform when studying religionand yes the study of religion, including explanatory endeavors, is an act of performance (cf. Bell 1998; 1997). The definition of theory that I offer to my students to grapple with (and critique) is as follows:

Theorization of religion is less a set of approaches or methodologies for the study of a given data set understood as "religion", than it is a (reflexive) analysis of the various and sometimes contending positioning acts taken in the very emergence of such a concept.

To study religion theoretically, therefore, is to study the power dynamics by which a constituted "normative" or "commonsense" object (= religion) arises for one set of social actors in relation to other sets of social actors.

In other words, we are looking at the how and "to what ends" such approaches/methodologies arise and are seen by social actors as viable tools for constructing "knowable knowledge".

As I look over this definition of theory, the following points strike me:

(1) A distinction between method and theory (i.e., to theorize is not to offer tools, but to explain the existence and use of analytical tools)

(2) Taxonomies establish power relations between social actors (and the roles played out or contested; here I'm reminded of Positioning Theory from social psychology; cf. Harré 1992; Harré and Langenhove 1999; 1992; Harré and Slocum 2003). (3) Theorizing is a reflexive process; the theorist can-and should - also be theorized.

(4) To theorize is to look at normative processes; i.e., how abstract and constructed concepts or impressions are internalized and rendered norma-

BULLETIN FOR THE STUDY OF RELIGION 1

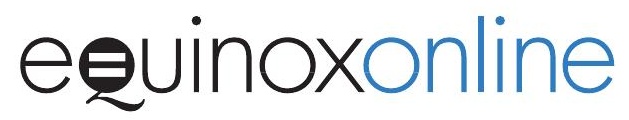


tive (here objects arise from concepts and are internalized by social actors to create new concepts from which further objects are created).

(5) All knowledge (and, by extension, all theory) is historically contingent (culturally, historically, ideologically).

(6) Knowledge contends with other knowledge and is often generated or modified within such confrontation (though conflict models need not be the only model of interaction used in studying such interaction).

(7) To theorize is not to look at what something is, but what it does (and for whom and under what social conditions).

To return to Foucault's operating table, to do method is to use the tools we have to study the data we have delimited into a data set, whereas to theorize is to explain the layout of the table, the assumptions at work in the diagnosis and medical procedure taken, and to discover the emergence of the operating table as a functioning reality for those in the room. To theorize, therefore, is not to engage in operating on the body before us, nor to belittle or delegitimize the processes at play or to mock those doing the operating. Theory can be positive, engaging, and helpful. I think we forget this aspect of theory when we "do theory" in some theory circles.

I also think method benefits from theory. Theory gives the researcher a vantage point from which to view how and, most importantly, why they use the analytical tools that they do. Theory offers us an orientation, a perspective by which we use (or abuse) the tools in hand. Theory also allows us to reflexively see our place in the history of a discipline, to perhaps recognize the situatedness of our own knowledge-making endeavors. Theory gets us to look at how social actors-scholarly actors or non-scholarly-use their taxons to negotiate the commonsense realities within which they live (what sociologists have called social constructionism for well over half a century; notably Blumer 1969 and Berger and Luckmann 1967; cf. Mack 2000). When we theorize, we explore the data producers and not just the data.

There remain problems in this more epistemological rather than methodological take on theory. Often, we forget that theorists are also data producers. And theorists often forget this truism as well. We are all engaged in producing data from the contingent realities that we exist within-be that a national context of hyper-social polarities, a specific academic organization where we "talk to" other theorists of like mind, our personal histories (what happens to us shapes how we view the world), professional advancements or impediments (again, what happens to us shapes how we view the world), or other factors arising from the diverse identities (or "hats") that we wear emerging from intersectional identity markers. I've noticed that many theorists who advocate self-reflexivity rarely engage in such reflexivity in their own work. Yet they create data and thus are data to theorize.

For theory to impact the broader field of religious studies, we need to shatter the cliques that arise in theory circles. I recall some years ago when the editorship of the Journal of the American Academy of Religion was up for nominations. Several theorists I knew in the field bemoaned the state of the field's flagship journal, claiming that the academy was now overrun by theologians and social activists rather than promoting theory in the study of religion. This was a typical slamming on others in the field (i.e., AAR-bashing) and my response was to encourage them or someone from their intellectual circle to apply for the editorship, to try to shape and redirect the field in the direction they felt we should be going. They mocked me for my suggestion, clearly remaining comfortable within their small academic clique, calling such AARbashing theorizing and self-reflexivity. They were more comfortable being in an elite intellectual club than in engaging in the kind of work they were calling the rest of us to do.

Such self-marginalization of theory is a problem in our field, as it is in any field or discipline. However, it is also a form of cultural performance (to evoke Catherine Bell's insightful work on ritual theory; 1992, especially 37-46; 1997; 1998), where theorists become data producers not because they posit particular ideas, but because they engage in particular behaviors. Recently, I've been wondering if theory-building-as data producers interacting with each other in their distinct cliques - is less a logocentric process than an affective and performative dynamic of social interaction (cf. Schaefer 2015; cf. proximity studies from cultural geography Thomlinson 2000; Torre and Rallet 2005). As Bell aptly put it, "performance analysis shifts the emphasis from how some system is expressed in these activities to how this performance simultaneously invokes (and thereby both constructs and plays off) a strategically defined set of terms, values, and activities" (1998, 216-17). Such invocation of values through activities serves to reinforce in-group identities by creating the out-group, facilitating interdependent group identity through solidarity against a mutually established "other". I'm reminded of Stephen Mennell's insightful discussion of "we-images" arising within expanding or contracting "survival groups," i.e., "the level of social organization which for the time being meets the most significant proportion its members' needs for survival" $(1998,188)$. The fluidity and acti- 
vation of identity is a fascinating perspective to apply to an academic field of study (cf. Rebillard 2012 on identity activation in antiquity). Once again, we have a positive side to what could be a negative use of theory if we look at such interactional dynamics as something to theorize. We have more data to explain, in this case the very people claiming to do theory.

Theory matters. And, perhaps, more important than theory is the ability and willingness of scholars to dialogue about theory. My own understanding of theorization is surely not the only way that those in the field will conceive of theorizing. We will disagree, debate, and (hopefully) learn from each other. But at least we will be discussing theory! Taking it seriously, while pushing colleagues-and ourselves-beyond our comfortable frameworks. We will cease seeing theory as either an obstruction to the study of religion or as a self-designation to propel ourselves into elitist self-satisfaction in opposition to those trying to study religion.

To return to my opening question-"Is there room for theory in religious studies?"-let me answer in the affirmative: yes, theory is not only valuable for the study of religion, it is essential and, more pointedly, inevitable. We are always theorizing, framing, shaping, directing, reflecting, and transforming. To theorize, however, is to do so in a formal, openly reflexive performance that will result in further transformation in the field (thus turning us into data producers in need of theorization). But such theorization needs to move beyond the confines of a small group of scholarly friends who simply talk to each other. It needs to be an ongoing disciplinary endeavor that intersects disciplines, traces disciplinary histories or genealogies, and critically challenges scholars using diverse methodologies to recognize the operating tables upon which they practice knowledge-making.

This issue of the Bulletin offers a wide range of articles engaging methods, theories, and the state of the field in various specialized areas of study. Reflections on a possible post-theoretical shift in the field, an overview of current scholarship in a subfield of religious history, or the theoretical implications of the rising geographies of religion approach in cultural geography all offers room for us to reassess, reflect upon, and debate the directions our field is moving along (and there is no one direction that dominates religious studies in 2019). My hope is that these pieces will push us to explore not only "religion" but the academic study of religion with greater nuance, intensity, and critical sophistication.

Philip L. Tite

\section{References}

Bell, Catherine. 1992. Ritual Theory, Ritual Practice. Oxford: Oxford University Press.

- 1997. Ritual: Perspective and Dimensions. Oxford: Oxford University Press.

1998. "Performance." In Critical Terms for Religious Studies. Edited by Mark C. Taylor, 205-24. Chicago: University of Chicago Press.

Berger, Peter, and Thomas Luckmann. 1967. The Social Construction of Reality. New York: Anchor Press.

Blumer, Herbert. 1969. Symbolic Interactionism: Perspective and Method. Englewood Cliffs, NJ: Prentice-Hall. https: / / doi.org/10.2307/2574696.

Foucault, Michel. 1994 [1970; French 1966]. The Order of Things: An Archaeology of the Human Sciences. New York: Vintage.

Harré, Rom. 1992. "What's Real in Psychology: A Plea for Persons." Theory and Psychology 2.2: 153-58.

Harré, Rom, and Luk van Langenhove, editors. 1992. Positioning Theory: Moral Contexts of Intentional Action. Oxford: Blackwell.

- 1999. "Varieties of Positioning." Journal for the Theory of Social Behaviour 20: 393-407.

Harré, Rom, and Nikki Slocum. 2003. "Disputes as Complex Social Events: On the Uses of Positioning Theory." Common Knowledge 9 (1): 100-18. https: / / doi.org/10.1215/0961754x-9-1-100.

Mack, Burton L. 2000. "Social Formation." In The Guide to the Study of Religion. Edited by Willi Braun and Russell T. McCutcheon, 283-96. London: Cassell.

Mennell, Stephen. 1998. "The Formation of We-Images: A Process Theory." In Social Theory and the Politics of Identity. Edited by Craig Calhoun, 175-97. Oxford: Blackwell.

Schaefer, Donovan O. 2015. Religious Affects: Animality, Evolution and Power. Durham: Duke University Press. https:/ / doi.org/10.1111/rsr.12378.

Stausberg, Michael, and Steven Engler. 2016. “Theories of Religion." In The Handbook of the Study of Religion. Edited by Michael Stausberg and Steven Engler, 5272. Oxford: Oxford University Press. https:/ / doi.org/10.1093/iaarel/lfx053.

Rebillard, Eric. 2012. Christians and Their Many Identities in Late Antiquity, North Africa, 200-450 CE. Ithaca: Cornell University Press. https: / / doi.org/10.1017/s0038713413004090.

Thomlinson, John. 2000. "Proximity Politics." Information, Communication \& Society 3 (3): 402-14.

Tite, Philip L. 2003. "Is There Room for Theory in Religious Studies?" ARC: The Journal of the Faculty of Religious Studies, McGill University 31: 1-12.

Torre, Andre, and Alain Rallet. 2005. "Proximity and Localization." Regional Studies 39 (1): 47-59. 